\title{
Problems of legal regulation of Kazakhs migration in the Altai Mining District in the second half of the XVIII - the middle of the XIX century: general imperial and regional practice
}

\author{
DOI: $10.31551 / 2410-2725-2018-4-4-499-510$
}

\author{
Anisimova Inna Vladimirovna \\ Candidate of History, Associate Professor of Oriental studies of the Altay State University. The Russian \\ Federation, 656049, Barnaul city, Lenin Ave.,61. E-mail: iva0410@mail.ru
}

\begin{abstract}
On the basis of a wide range of sources, the article analyzes the Russian Empirepolicy in relation to the Kazakh migration movement to the Altai mountainous area in the second half of the 18th and the mid-19th century. Active migration processes in the southern Siberian region of the mid-18th century were caused by a complex of foreign-policy reasons (the aggression of the Qing Empireand the defeat of the Dzungars) and domestic political circumstances (deterioration of the social and economic situation in the Kazakh steppe, administrative reforms).The migration waveof the Kazakhs, which moved to the east, also seized the territory of the Kolyvan-Resurrection (since 1834 - Altai) mountain district. Russian political interests of influenced the formation of a special attitude to the process of regulating migration processes in the region. The central and the Siberian governments did not see any special obstacles for the resettlement of nomads to the territory of the Mountainous District on condition of a temporary stay. The liberal approach of the Russian authorities did not meet the interests of the mining department. Approaching the problem from the local positions, the board of the Mountainous District and the Cabinet negatively treated the Kazakhs' migration to the subordinate lands and demanded from the higher authorities decisive action to prevent them. In the first half of the XIX century discrepancies between the Russian central authorities and the local administration regarding the settlement of the migration movement and the registration of the status of the Kazakhs, who have migrated, have become more apparent. Administrative orders to prohibit the removal of labor were difficult to implement. Limit the migration flow was not possible. In the 1860 s regional authorities recognized the impossibility of the final removal of Kazakhs from the lands of the district, which required a change in approaches to the process of regulating the migration movement of Kazakhs in the region. Keywords: Russian Empire; Altai Mountainous District; Kazakhs; migration; state policy; regulation; legal status.

\section{XVIII ғасырдың екінші жартысы -XIX ғасырдың ортасында Алтай таулы округына қазақтардың көші-қонын құқықтық реттеу мәселелері: жалпыимпериялық және аймақтық тәжірибе}

\section{Анисимова Инна Владимировна}

тарих ғылымдарының кандидаты, Алтай мемлекеттік университетінің шығыстану кафедрасының доценті. Ресей Федерациясы, 656049, Барнаул қ. Ленин даңғылы, 61. E-mail: iva0410@mail.ru

Аңдатпа. Мақалада деректердің кең ауқымы негізінде XVIII ғасырдың екінші жартысында -XIX ғасырдың ортасында Алтай таулы округына қазақтардың көші-қон қозғалысына қатынасты Ресей империясының саясатына талдау жасалынады. XVIII ғ. ортасында Оңтүстік Сібір аймағындағы қарқынды көші-қон үрдістер сыртқы саяси сипаттағы (Цин империясының агрессиясы және Жоңғар хандығын талқандау) және ішкі саяси жағдайлармен (қазақ даласында әлеуметтікэкономикалық жағдайдың нашарлауы, әкімшілік реформалар) себептердің кешенімен туындаған. Қазақтардың шығысқа қозғалған көші-қон толқыны Колывано-Воскресенск ( 1834 ж. - Алтай) таулы округынының территориясында қамтыды. Ресейдің саяси мүдделері аймақта көші-қон үрдістерді реттеу үрдісіне ерекше қатынасты қалыптастастыруға әсер етті. Орталық үкімет және Сібір билігі Таулы округ территориясына көшпенділерді коныстандыру үшін, яғни олардың уақытша мекендеу жағдайында сондай бір кедергілерді байқамады. Ресейлік биліктердің либералды көзқарасы таулызаводтық ведомствоның мүдделеріне сай болмады. Таулы округ басшылығы және Кабинет мәселеге жергіліктілік ұстанымнан қарауы ведомстволық жерлерге қазақтардың көшіп-қоңуына жағымсыз қарап және жоғары тұрған инстанциялардан олардың алдын-алу бойынша шешуші әрекеттерді талап етті. XIX ғ. бірінші жартысында ресейлік орталық билік органдары және жергілікті әкімшілік арасында көші-қон қозғалыстарды реттеу мәселелері және көшіп келген қазақтардың статусын рәсімдеу бойынша қайшылықтар айқындала түсті. Құқықтық қорғау шараларына қарамастан, көші-қонағымды шектеу мүмкін болмады. Округтың қазақ халқының саны жыл сайын артты, ал оларды қоныс аудару жетістіктер бермеді. XIX ғ. 60- 
жылдары аймақтық билік округ жерлерінен қазақтарды түпкілікті ығыстыру

мүмкіндігі болмайтындығын түсінді, яғни бұл аймақта ұлттық саясатты өзгертуді қажет етті.

Түйінді сөздер: Ресей империясы; Алтай таулы округы; қазақтар; фронтирлік көші-қон; мемлекеттік саясат; регламентация; құқықтық статус.

\title{
Проблемы правового регулирования миграции казахов в Алтайский горный округ во второй половине XVIII - середине XIX в.: общеимперская и региональная практика
}

\section{Анисимова Инна Владимировна}

кандидат исторических наук, доцент кафедры востоковедения Алтайского государственного университета. Российская Федерация, 656049, г. Барнаул, пр. Ленина, д.61. E-mail: iva0410@mail.ru

\begin{abstract}
Аннотация. В статье на основе широкого круга источников проводится анализ политики Российской империи в отношении миграционного движения казахов на территорию Алтайского горного округа во второй половине XVIII - середине XIX в. Активные миграционные процессы в южносибирском регионе середины XVIII в. были вызваны комплексом причин внешнеполитического характера (агрессия Цинской империи и разгром Джунгарского ханства) и внутриполитическими обстоятельствами (ухудшение социально-экономической ситуации в казахской степи, административные реформы). Мощная миграционная волна казахов, двинувшаяся на восток, захватила также территорию Колывано-Воскресенского (с 1834 г. Алтайского) горного округа. Политические интересы России повлияли на формирование особого отношения к процессу регламентации миграционных процессов в регионе. Центральное правительство и сибирские власти не видели особых препятствий для переселения кочевников на территорию Горного округа при условии временного пребывания. Либеральный подход российских властей не отвечал интересам горнозаводского ведомства. Правление Горного округа и Кабинет, подходя к проблеме с местнических позиций, негативно относились к перекочевкам казахов на подведомственные земли и требовали от вышестоящих инстанций решительных действий по их пресечению. В первой половине XIX в. расхождения между российскими центральными органами власти и администрацией на местах по вопросам урегулирования миграционного движения и оформления статуса прикочевавших казахов стали более очевидными. Несмотря на правовые охранительные меры ограничить миграционный поток не удавалось. Ежегодно казахское население Округа возрастало, а их выселение не имело успеха. В 60-е гг. XIX в. региональными властями была признана невозможность окончательного удаления казахов с земель округа, что требовало изменения национальной политики в регионе. Ключевые слова: Российская империя; Алтайский горный округ; казахи; фронтирные миграции; государственная политика; регламентация; правовой статус.
\end{abstract}

\section{әОЖ/ УДК 93/94}

\section{Проблемы правового регулирования миграции казахов в Алтайский горный округ во второй половине XVIII - середине XIX в.: общеимперская и региональная практика}

\section{И.В. Анисимова}

Введение. Формированию современного полиэтнического состава региона, как правило, предшествуют сложные исторические события, совокупность политических и социально-экономических фракторов, обусловливающие миграционную подвижность народов. В середине XVIII в. российские власти столкнулись с мощным миграционным движением казахов, вызванным разгромом Джунгарского ханства в 1755-1759 гг., изменением традиционных маршрутов кочевания, теснотой в казахской степи. Российское правительство в отношении переселения казахов и регламентации данного процесса исходило из политических и экономических приоритетов государства. Существенную роль в формировании выбранного курса играл и «внешний фрактор» в 
лице Цинской империи. После разгрома Джунгарии Цины заявили о своих претензиях на «джунгарское» наследство и угроза вторжения китайских войск на территорию русского Алтая была вполне очевидна. Второй составляющей данного фактора стала негласная борьба между Россией и Китаем за влияние в казахской степи и приведение казахов из номинального в фрактическое подданство. Умеренная позиция центральных органов власти шла в разрез с интересами Колывано-Воскресенского горнозаводского ведомства, территорию которого, в первую очередь, затронули миграционные потоки. Администрация Горного округа настаивала на решительном запрете переселения казахов на подведомственную территорию. На протяжении первой половины XIX в. расхождения в подходах к решению проблемы казахских переселенцев на территорию горнозаводского ведомства становились более заметными. Несмотря на стремление региональных властей ограничить миграционные процессы и закрыть Алтайский горный округ от переселения кочевников, казахское население региона ежегодно увеличивалось, что, в итоге привело к необходимости регламентации их правового статуса.

Материалы и методы. Источниковую базу исследования составили документы и материалы, отложившиеся в центральных и региональных архивах: Центральном государственном архиве Республики Казахстан (Ф. 15 Семипалатинское областное правление, Ф. 338 - Омское областное правление Министерства иностранных дел, Ф. 478 - Семипалатинская таможня Департамента таможенных сборов Министерства фринансов); АВПРИ (Ф. Зюнгорские дела); Государственном архиве Алтайского края (Ф. 2 - Алтайское горное правление, Ф. 4 - Горное управление Алтайского округа); Государственном архиве Омской области (Ф. 2 - Сибирский генерал-губернатор); Государственном архиве Томской области (Ф.144 - Чертежная Томского губернского управления). Архивные материалы представляют собой делопроизводственную документацию (отчеты, донесения, деловая переписка между органами власти различного уровня). Данные документы позволяют проследить характер и аргументацию позиций, выявить разногласия региональных и центральных органов власти по вопросам миграционного движения казахов и их положения на территории Алтайского горного округа. Отдельную группу источников представляют документы законодательного характера. Здесь особое значение имеет сборник законодательных актов, составленный чиновником Тургайского областного правления И.И. Крафттом (Крафрт, 1898), документы которого позволяют реконструировать официальную позицию властей в отношении миграционного движения казахов на территорию российских губерний.

В исследовании реализуется принцип историзма, способствующий провести объективный анализ изучаемого явления. Методический инструментарий состоит из комплекса исторических методов исследования: историкогенетический, историко-сравнительный, историко-типологический, историкосистемный, в совокупности с общенаучными методами.

Обсуждение. Отдельные аспекты истории миграционного движения казахов на территорию Алтайского горного округа во второй половине XVIII середине XIX в. и проблемы его регламентации были затронуты уже дореволюционной историографией. Наиболее полно заявленная проблематика получила освещение в исследованиях И.Г. Андреева, Е. Шмурло (Андреев, 1998; Шмурло, 1995). Е. Шмурло подчеркивал, что присутствие казахов на западе и юго-западе горного ведомства делали эти территории наиболее 
проблемными для администрации Округа, обостряя и без того сложные отношения по земельным вопросам.

Советская историография рассматривала различные аспекты проблем миграционного движения казахов в сопредельных районах Южной Сибири и Казахстана, уделяя, прежде всего, внимание процессу освоения юга Западной Сибири, фрормированию населения Алтая, развитию русско-казахского взаимодействия (Аполлова, 1976; Уманский, 1980; Алексеенко, 1981).

В последние десятилетия интерес к заявленной проблеме существенно возрос. Особое значение имеют исследования, представляющие анализ процесса фрормирования национальной политики Российской империи в целом, а также рассматривающие особенности региональных стратегий и практик в решении национальных вопросов (Дамешек, 1986; Шерстова, 2000; Дамешек, 2018). Согласимся с мнением Л.И. Шерстовой, что российская государственная политика формировалась в русле «евразийской традиции», в том числе в рамках данной традиции вырабатывалось и отношение российских властей к иноэтническим социумам. Согласно теории евразийства, Русское государство, находясь с сибирскими землями и сопредельными регионами Центральной Азии в так называемой исторической, естественной государственной связи, стремилось инстинктивно воссоздать единство, созданное Чингисханом (Трубецкой, 2002: 208-265). Отсюда, суть «евразийской политики» в России определялась несколькими главными установками: непротивопоставление населявших ее этносов друг другу по этнокультурному признаку; восприятие иноэтнических элементов не как чуждого этнически, расово, конфессионально контингента, а прежде всего, как «государевых подданных», как податного сословия, при этом этнорасовая принадлежность была несущественна (Шерстова, 2003).

Серия работ отечественных ученых посвящена анализу русско-казахского взаимодействия (Алексеенко, 2003; Карих, 2004; Лысенко, Анисимова, 2013). Исследователями подчеркивается, что на протяжении XVIII-начала XX вв. территория Алтая выступала зоной активных межкультурных контактов, в результате которых здесь сформировалась не имевшая аналогов универсальная модель этносоциальных отношений. Отдельное место в данной модели межэтнических отношений принадлежало русско-казахскому взаимодействию.

Важным является вывод отечественной историографии, что результатом миграционного движения стало фрормирование казахской диаспоры Алтая, представленной рядом локальных групп (Ермекбаев, 1999; Наумова, 2000; Октябрьская, 1997; Октябрьская и др., 2001). Более критично к оценке результатов миграционного движения подходят в казахстанской историографии, характеризуя казахскую диаспору как «диаспору - жертву», обосновывая причину формирования казахских этнических групп за пределами казахской степи колониальной политикой царизма (Валиханов, 2001; Мендикулова, 2002).

Безусловно, высокий интерес к проблеме обусловлен актуальностью темы. Введение в оборот новых архивных материалов позволит составить более взвешенную оценку моделей и результатов государственной политики центрального, регионального (сибирского) и местного (алтайского) уровней власти в отношении миграционного движения казахов на территорию Алтайского горного округа в рассматриваемый период.

Результаты. Одной из отправных точек формирования казахского населения региона стали события середины XVIII в., связанные с разгромом цинскими войсками Джунгарией. Падение Джунгарского ханства вызвало активное миграционное движение казахов в приграничных с Россией областях. 
В том числе, одна из миграционных волн затронула и территорию КолываноВоскресенских горных заводов, которая к этому времени носила статус императорской вотчины, была личной собственностью царской семьи и строго оберегалась от внешних вторжений. С 1742 г. вся громадная территория Алтая была поставлена под управление «Кабинета Ея Величества», одновременно с возникновением кабинетского хозяйства на Алтае был учрежден округ Колывано-Воскресенских (с 1830 г. - Алтайских) горных заводов. Новый юридический статус заводов был закреплён указом 1747 г., в котором говорилось о необходимости не только укрепить уже имеющиеся крепости, но и построить ряд новых, снабдить их артиллерией и обеспечить необходимым количеством регулярных и нерегулярных войск ${ }^{1}$, что было обусловлено и необходимостью повышения обороноспособности ведомства, и защитой частной собственности императора. Особый статус горно-металлургической отрасли Алтая предопределил широкие привилегии, в том числе и в управлении и позволил руководству Горного ведомства не только высказывать, но и отстаивать свою позицию в отношении миграционного движения казахов.

Необходимо отметить, что во второй половине XVIII в. «внешний фактор» в политике России в отношении миграционного движения казахов на территорию Южной Сибири играл едва ли не определяющую роль. В условиях русскокитайского противостояния правительство направило свои действия на утверждение своего влияния в казахских жузах. Принятие казахами цинского подданства во многом осложнило бы ситуацию на российских границах. В связи с этим, в 80-90-е гг. XVIII в. в российских политических кругах появился ряд проектов, направленных на усиление позиций России в казахской степи. Среди них можно выделить проект князя Г.А. Потемкина-Таврического, предусматривающий переход казахов Среднего жуза к оседлому образу жизни, а также проект генерал-майора Я. Боувера, который предполагал реализацию мероприятий, направленных на просвещение и обучение казахов (Басин, 1971: 246-249). Кроме того, российские власти на протяжении второй половины XVIII в. проводили в отношении казахской степи комплекс мер социальноэкономического характера, который включал организацию льготной торговли, снижение таможенных пошлин, снабжение казахских султанов хлебом, выплата им жалования, строительство домов и т.д. Русско-китайское соперничество в азиатском регионе, стремление укрепить свое политическое влияние в казахской степи объясняло умеренную позицию правительства России по отношению к миграционному движению казахов в пределы империи, a нередко требовало большей либерализации в решении вопроса о переселении казахов. В связи с этим, одной из мер, направленных на улучшение русско-казахских отношений стало разрешение на перекочевку казахов на территорию Тобольской и Томской губерний, в том числе на территорию Колывано-Воскресенских горных заводов. В 70-90-е гг. XVIII в. было издано несколько указов, закрепляющих за казахами права кочевать «на свободных сибирских землях» (Крафтт, 1898: 139-140).

Однако, уже на данном этапе, в процессе регламентации миграционного движения казахов на территорию Горного ведомства начали проявляться расхождения позиций центральной и местной властей. Российское правительство подходило к проблеме с общегосударственных позиций, не учитывая локальные интересы региона. Сибирские власти рассматривали проблему с региональных позиций, были заинтересованы в расселении

\footnotetext{
${ }^{1}$ Архив внешней политики Российской империи (АВПРИ). Ф. Зюнгорские дела. Оп. 113/1. 1747 г. Д. 3. Л. 4об. -5.
} 
казахов на свободных землях, в том числе на землях горного округа. Администрация округа и Кабинет, выступая против переселения казахов в пределы ведомства, выражали, прежде всего, интересы императорской семьи и выступали за неприкосновенность частной собственности.

C начала XIX в. «казахский вопрос» в китайско-русских отношениях начинает утрачивать свою актуальность. Цинский двор на западных рубежах своей империи отказывается от политики дальнейшей экспансии в Центральной Азии и придерживается «изоляционистского курса» в отношении России (Кузнецов, 1983: 113). Присутствие российской власти в подавляющей части казахских кочевий, сопредельных с цинскими пикетами, стало непреложным фактом, как следствие этого происходило падение авторитета Цинской империи. Несмотря на изменения внешних обстоятельств, общий умеренный курс в отношении миграции казахов на сибирские земли сохранился. Уже в 1809 г. российским правительством были разработаны условия выделения земли под кочевки для казахов, мигрировавших на территорию Горного округа. Согласно принятому положению, в 40-верстной полосе по левому берегу Иртыша все свободные земли казахам разрешалось использовать под хлебопашество, сенокосы и пастбища для скота. Допускался отвод земли казахам и за чертой крестьянских селений в Томской губернии с согласия губернских и казахских представителей, но не далее 30 верст от линии и не ближе 40 верст к деревням. Земля отводилась с учетом количества кибиток и скота. Казахам с этих участков запрещался переход на казачьи земли и приближение к казачьим и крестьянским пашням и покосам (Бекмаханова, 1980: 139). Тогда же Томский гражданский губернатор потребовал от горного начальства назначения мест под поселения выходящих из-за границы иноверцев. Польза «важного», по мнению сибирских властей, «приобретения» заключалась в обеспечении безопасности на сибирских границах ${ }^{2}$.

Однако, такая политика расходилась с позицией Колывано-Воскресенского округа, администрация которого в начале XIX в. все настойчивее начинает требовать от сибирских и центральных властей принятия решений, запрещающих миграцию казахов в пределы округа. Руководство Горного округа принимало меры, шедшие вразрез с общегосударственными положениями. Свое негативное отношение к миграции казахов горное ведомство объясняло тем, что казахи, прикочевавшие в КолываноВоскресенский округ, «будучи по своему образу жизни чужды условиям гражданской правовой жизни, сразу стали в неприязненные отношения к местному крестьянскому населению, посягая на его собственность - похищая лошадей, истребляя на полях хлебные посевы, самовольно пася скот на крестьянских лугах» ${ }^{3}$.

Причины жесткой по отношению к миграции казахов позиции лежали в особенностях экономической системы Округа в центре которой находилась горнодобывающей промышленности с использованием труда приписного крестьянства, при этом возможность использования других ресурсов региона, в том числе земельных считалась нецелесообразной. В 1809 г. начальник Колывано-Воскресенского горного округа в одном из донесений в Кабинет Е.И.В. подчеркивал, что «водворение киргизцев в заводское ведомство не только не может быть удобным, но послужит в земледелии и прочих по крестьянскому быту промыслах стеснением; а еще более по нравам киргизцев

\footnotetext{
${ }^{2}$ Государственный архив Омской области (далее - ГАОО). Ф. 2. Оп. 1. Д. 183. Л. 2

${ }^{3}$ Государственный архив Алтайского края(далее - ГААК). Ф. 4. Оп. 1. Д. 3330. Л. 9 об.
} 
можно ожидать какого-либо своевольства и раздоров между ними и местными жителями к затруднению начальства» ${ }^{4}$. Учитывая позицию руководства Горного округа, Кабинет летом 1809 г. предписал «для поселения киргизцев и подобного рода людям земель в ведомстве заводском не отводить» ${ }^{5}$. Начальник Колывано-Воскресенских горных заводов П.К. Фролов неоднократно обращался в вышестоящие инстанции о необходимости либо выселить казахов, мигрировавших на подведомственную ему территорию, либо регламентировать их положение и статус. Учитывая такую позицию руководства Округа, в последующем запрет о выделении казахам земель в Горном ведомстве был неоднократно Кабинетом подтвержден (в 1809, 1810, 1815 гг. $)^{6}$. Более того, в 1821 г. сенатским указом было утверждено постановление генерал-губернатора Сибири М.М. Сперанского об исключении территорию горнозаводского ведомства из фонда земель, предполагаемых использовать под отвод казахам ${ }^{7}$. Резкую критику со стороны горнозаводской администрации вызвал и принятый в 1822 г. Устав «Об управлении сибирскими инородцами», согласно которому вводилось новое положение об административно-территориальном устройстве казахов внутренних и внешних округов, а также отводились временные кочевья на заводских землях и в южных округах Томской губернии (Дамешек, 1986). Тем самым Устав затрагивал интересы Горного округа и Кабинета, что привело к активному обсуждению проблемы, длившейся несколько лет. В итоге, в 1824 г. было принято постановление о запрете казахам кочевать на принадлежащих заводскому ведомству землях (Лысенко, Анисимова, 2013: 34-35).

Однако, несмотря на официальную позицию Кабинета и руководства Горным ведомством, запрещающую переселения, остановить миграционные процессы региональные власти были не в состоянии. Казахи, перекочевывая на территорию Округа, активно включались в экономическую систему региона. В Правление Алтайского горного округа поступало значительное количество обращений о предоставлении казахам права не только кочевать в пределах Округа, но и заниматься хозяйственной деятельностью. Нередко кочевников приглашали сами крестьяне, мотивируя свои просьбы тем, что казахи «доставляют значительное пособие по управлению их хозяйством» ${ }^{8}$. Администрация горнозаводского ведомства стремилась искоренить практику найма казахов населением округа, неоднократно подтверждая запрет «киргизцев ни под каким видом в услужение и на места заводские не принимать» ${ }^{9}$. Нередко казахи, неоднократно кочующие на землях Горного ведомства, обращались с просьбой узаконить свое положение и причислить их к приписным крестьянам Округа. Рассмотрение таких просьб вновь выявляло расхождение в решении данного вопроса между региональными властями в лице Алтайского горного правления с одной стороны и западносибирской администрации, в частности, Томского гражданского губернатора, с другой. Как правило, западносибирские власти не видели существенных препятствий к переселению казахов на свободные земли округа и причислению их к приписным крестьянам. Иной позиции придерживалась администрация Алтайского горного округа, которая выступала резко против причисления кочующих казахов к крестьянскому сословию.

\footnotetext{
${ }^{4}$ ГААК. Ф. 2. Оп. 1. Д. 2059. Л. 25-26

${ }_{5}^{5}$ ГААК. Ф. 2. ОП. 1. Д. 2059. Л. 26 об.

${ }^{6}$ ГААК. Ф.4. Оп. 1. Д. 3330. Л. 9 об. - 10; Ф. 2. Оп. 2. Д. 77. Л. 228, 229

${ }^{7}$ Центральный государственный архив Республики Казахстан - ЦГА РК. Ф. 478. Оп. 2. Д. 8. Л. 128-129

${ }^{8}$ ГААК. Ф. 2. ОП. 1. Д. 378. Л. 1-5

${ }^{9}$ ЦГА РК. Ф. 338. Оп. 1. Д. 663. Л. 15
} 
На протяжении 30-х гг. XIX в. администрация Алтайского горного округа неоднократно подтверждала свою позицию запретами на переселение казахов на подведомственную территорию, инициировала дела о выселении прикочевавших казахов, вступала в переписку с вышестоящими инстанциями о необходимости разрешения проблемы в пользу Горного ведомства. Итогом многолетней переписки стало принятие в 1842-1843 гг. западносибирским генерал-губернатором П.Д. Горчаковым и Тобольским губернским советом ряда постановлений, отражающих интересы Алтайского горного округа. Принятые нормативно-правовые акты содержали запрет на постоянное поселение и временную кочевку в пределах горнозаводского ведомства ${ }^{10}$. Но, несмотря на постановление сибирских властей удалить казахов с территории Горного округа не удавалось. В этой связи, Алтайское правление своим решением предложило казахов, кочующих на местах горного ведомства около заводских селений, «вывесть на другие места, не заселенные крестьянами, не занятые заведениями, назначив для кочевки дистанцию, так чтобы отведенные для киргиз на этой дистанции места находились к селениям не ближе 40 верст» ${ }^{11}$. Предполагалось, что эти меры остановят несанкционированное переселение казахов. Но, в итоге, ожидаемые результаты не были получены. В 1849 г. Алтайское горное правление вновь подчеркивало, что необходимо «воспретить переселения и другим киргизам, которые бы стали просить о том, ибо заводское начальство не только не ожидает пользы от переселения сих инородцев, но опасается, что оно может даже стеснить как местных жителей, так и самые заводы: затруднить перевозку руд и прочее» ${ }^{12}$. Следует признать, что присутствие казахов на территории горнозаводского ведомства таило в себе потенциальную и реальную опасность. В местах компактного проживания казахов и местного населения значительно возрастала вероятность напряженности. Там, где границы пролегали по линии земледельческого фронтира - линии соприкосновения земледельческой культуры с кочевым укладом, они образовывали как бы буферную территорию со стабильно высокой конфрликтностью, постоянными набегами и столкновениями. Отсюда, многочисленные жалобы местного крестьянского населения на беспорядки и преступления, чинимые казахами.

В середине XIX в. казахи располагали свои кочевья не только в сопредельных с казахской степью районах, но и «проникли вглубь» горнозаводского ведомства, все ближе подходя к крестьянским селениям. Неизменно возрастала и численность казахского населения округа. Так, в середине 30-х гг. XIX в. по собранным Алтайским горным правлением сведениям на территории округа кочевало 8605 казахов, к 50-м гг. эта цифра увеличилась практически вдвое, к середине столетия только станичных казахов, проживающих на землях Сибирского казачьего войска и переходящих на кочевья в Кулундинскую степь, было уже 16 тыс. чел. Безусловно, эти фракты свидетельствуют о малоэффективности предпринимаемых к выселению казахов с территории Горного ведомства мер.

Вначале 50-X гг. XIX в. администрация Алтайского горного округа вновь инициировала вопрос о немедленном и совершенном выселении казахов с земель ведомства. В результате рассмотрения дела Главным управлением Западной Сибири и пограничным начальником Сибирских киргизов были собраны сведения о численности кочующих казахов, местах их компактного

\footnotetext{
10 ГААК. Ф.2. Оп. 2. Д. 8532. С. 35-38

${ }^{11}$ ГААК. Ф.2. Оп. 2. Д. 8532 . Л. 38

12 ГААК. Ф. 2. Оп. 1. Д. 594. Л. 4
} 
расселения в Горном округе ${ }^{13}$. В марте 1852 г. генерал-губернатор Западной Сибири Г.Х. Гасфорд выступил с предложением, реализация которого могла бы успешно решить проблему переселения казахов в пределы Горного округа. Гасфрорд предлагал «...приписать казахов по месту их кочевания к ближайшим сотням линейного войска и подчинить надзору и управлению сибирского казачьего войска; из всех аулов и волостей, кочующих на внутренней пустынной стороне, образовать особый округ, под управлением Пограничного управления, а затем всех киргиз, кочующих по близости заселенных мест горнозаводского ведомства, вывести на внешнюю сторону в те округа, к которым они причислены» ${ }^{14}$. Однако, осуществление этих мер было затруднено, в том числе, наличием фронда свободных земель во внешних округах для предоставления переселяемым казахам.

Пожалуй, одним из наиболее действенных актов, регламентирующих переселение казахов на земли Алтайского горного округа, стало принятое в 1854 г. положение Сибирского комитета «О прекращении в Западной Сибири конокрадства», согласно которому все кочующие на землях Горного округа казахи выселялись за черту земель Горного ведомства, с запрещением им, согласно § 94 положения «Об управлении Семипалатинской областью», переходить в горный округ на кочевья и земли крестьянских селений. Частично, данный нормативно-правовой акт сумел ограничить миграции казахов, но, полностью оградить Округ от переселения не удалось.

Имперские ресормы 60-х гг. XIX в. привели к формированию в экономике Алтайского горного округа качественно новой ситуация, которая была связана с капиталистической модернизацией, заменившей труд приписного крестьянства на вольнонаемный труд, а монопрофильное горнозаводское производство - на диверсифицированную структуру хозяйства. Началась трансформация алтайского производственно-территориального комплекса, в ходе которой осуществлялась смена системы хозяйствования с доминирования горнопромышленного сектора на диверсифицированную структуру по эксплуатации недр, земельно-лесных, водных и других ресурсов региона. Особую роль в этом процессе играло развитие земельно-арендной отрасли (Кухаренко, 2012: 146). Это кардинально изменило отношение руководства Алтайского округа к вопросу о миграции казахов на его территорию и впервые позволило конструктивно решать вопрос земельного устройства кочевников в пределах данной административной единицы (Лысенко, Анисимова, 2013: 174). Эти качественные изменения привели к формированию новых имперских и региональных практик правового регулирования положения казахов, кочующих в пределах Алтайского горного округа.

Заключение. Таким образом, одной из актуальных проблем национальной политики Российской империи на протяжении второй половины XVIII середины XIX в. стало массовое переселение казахов на земли Алтайского горного округа. Причинами активных миграционных процессов были как внешние фракторы, так и политические и социально-экономические процессы в казахской степи. Центральные и региональные органы власти по-разному видели процесс регламентации активного миграционного движения, исходя их политических и социально-экономических интересов. Имперская практика правого регулирования миграции казахов носила достаточно умеренный характер, законодательно закреплялось право казахов на переселение вглубь российских губерний. В том числе, центральные органы власти видели

${ }^{13}$ ГАТО. Ф. 144. Оп. 1. Д. 377. Л. 1-2

${ }^{14}$ ЦГА РК. Ф. 15. Оп. 1. Д. 1774. Л. 13-15 
возможным и целесообразным переселение казахов и в пределы горнозаводского ведомства. На региональном уровне власти, представленном администрацией Колывано-Воскресенского (Алтайского) горного округа при поддержке Кабинета, считалось недопустимым открытие территории ведомства для казахских кочевок. При этом, Правление горнозаводского ведомства исходило из принципов защиты интересов частной собственности императорской фамилии. В результате несогласованности действий и реализации разных практик правового регулирования данная проблема оставалась нерешенной. Несмотря на предпринимаемые Горным ведомством ограничительные меры, миграция казахов на территорию Алтайского Горного округа к середине XIX в. не претерпела существенных изменений. Более того, казахи постепенно занимали определенную нишу в социально-экономической системе Округа и проблема регламентации их правового статуса становилась для региональных властей все более очевидной. Существенные изменения в практике правового регулирования, связанные с землеустройством казахов, произойдут уже в пореформенный период.

\section{Әдебиеттер тізімі/ Список литературы}

1. Алексеенко Н.В. Взаимосвязи казахского и русского населения в Восточном Казахстане (XVIII - первая половина XIX вв.). - Усть-Каменогорск, 2003. - 139 с.

2. Алексеенко Н.В. Население дореволюционного Казахстана (численность, размещение, состав, 1870-1914 гг.). - Алма-Ата, 1981. - 111 с.

3. Андреев И.Г. Описание Средней орды киргиз-кайсаков. - Алматы, 1998. - 280 с.

4. Аполлова Н.Г. Хозяйственное освоение Прииртышья в конце XVI - первой половине XIX в. M., 1976. -372 c.

5. Басин В.Я. Россия и казахские ханства в XVI-XVIII вв. - Алма-Ата, 1971. - 274 с.

6. Бекмаханова Н.Е. Формирование многонационального населения Казахстана и Северной Киргизии. Последняя четверть XVIII - 60-е гг. XIX вв. - М., 1980. - 280 с.

7. Валиханов Э.Ж. Вопросы казахской государственности в XIX в. // Отан тарихы. - 2001. - №3. - C. 53-56.

8. Дамешек Л.М. Внутренняя политика царизма и народы Сибири (XIX - начало XX века). Иркутск, 1986. - 165 с.

9. Дамешек Л.М. Сибирские «инородцы» в имперской стратегии власти (XVIII - начало XX в.). Иркутск, 2018. - 456 с.

10. Ермекбаев Ж.А. Российские казахи в составе РСФСР и СССР в 1917-1991 гг. - Омск, 1999. $184 \mathrm{c}$.

11. Карих Е.В. Межэтнические отношения в Западной Сибири в процессе ее хозяйственного освоения. XIX - начало XX в. - Томск, 2004. - 232 с.

12. Крафт И.И. Сборник узаконений о киргизах степных областей. - Оренбург, 1898. - 884 с.

13. Кузнецов В.С. Цинская империя на рубежах Центральной Азии (вторая половина XVIII первая половина XIX в.). - Новосибирск, 1983. - 124 с.

14. Кухаренко А.Е. Дореволюционная и советская историография земельно-арендной политики Кабинета в Алтайском (горном) округе // Известия Алтайского государственного университета. 2012. - № 4-2. - С. 146-150.

15. Лысенко Ю.А., Анисимова И.В. Межэтнические процессы на Алтае в XVIII - начале XX века (на примере русского и казахского этносов). - Барнаул, 2013. - 176 с.

16. Мендикулова Г.М. Актуальные проблемы диаспорологии в Казахстане // Отан тарихи. - 2002. - №. 3-4. - C. 37-42.

17. Наумова О.Б. Казахская диаспора в России: этническое самосознание и миграционное поведение // Этнографическое обозрение. - 2000. - № 3. - С. 60-73.

18. Октябрьская И.В. Казахи Алтая. История и современность // Этнографическое обозрение. 1997. - № 6. - С. 92-102.

19. Октябрьская И.В., Осипова Л.П., Нечипоренко О.В. Туратинские казахи. Судьбы национальных меньшинств в России // Этнография Алтая и сопредельных территорий. Вып. 4. Барнаул, 2001. - С. 29-34.

20. Трубецкой Н. Взгляд на русскую Историю не с Запада, а с Востока // Основы Евразийства. М., 2002. - C. 208-265. 
21. Уманский А.П. Телеуты и русские в XVII-XVIII веках. - Новосибирск, 1980. - 296 с.

22. Шерстова Л.И. Влияние государственной политики на этнические процессы в Южной Сибири в первой половине XIX в. // Этнографическое обозрение. - 2000. - № 4. - С. 102-108.

23. Шерстова Л.И. Этнокультурные контакты русских и народов Сибири в XVII-XIX вв.: евразийский аспект // Степной край Евразии: историко-культурные взаимодействия и современность. - Астана - Омск - Томск, 2003. - С. 75-77.

24. Шмурло Е. Русские и киргизы в долине верхней Бухтармы // Царская колонизация в Казахстане. (По материалам русской периодической печати XIX века). - Алматы, 1995. - С. 21-79.

\section{References}

Alekseenko 2003 - Alekseenko, NV, Vzaimosviazi kazakhskogo i russkogo naseleniia v Vostochnom Kazakhstane (XVIII - pervaia polovina XIX vv.), Ust'-Kamenogorsk, 139 p. (Alekseenko, NV 2003, Interrelations of Kazakh and Russian population in East Kazakhstan (XVIII - first half of XIX centurie), Ust'-Kamenogorsk, 139 p). (in Rus).

Alekseenko 1981 - Alekseenko, NV, Naselenie dorevoliutsionnogo Kazakhstana (chislennost', razmeshchenie, sostav, 1870-1914 gg.), Alma-Ata, 111 p. (Alekseenko, NV 1981, Population of prerevolutionary Kazakhstan (number, location, composition, 1870-1914), Alma-Ata, 111 p). (in Rus).

Andreev 1998 - Andreev, IG, Opisanie Srednei ordy kirgiz-kaisakov, Almaty, 280 p. (Andreev, IG 1998, Description of the Middle horde of Kirghiz-Kaisaks, Almaty, 280 p). (in Rus).

Apollova 1976 - Apollova, NG, Khoziaistvennoe osvoenie Priirtysh'ia v kontse XVI - pervoi polovine XIX v., M., 372 p. (Apollova, NG 1976, Economic development of Irtysh region in the late 16th first half of the 19th century, M., 372 p). (in Rus).

Basin 1971 - Basin, VJa, Rossiia i kazakhskie khanstva v XVI-XVIII vv, Alma-Ata, 274 p. (Basin, VJa 1971, Russia and Kazakh khanates in the 16th-18th centuries, Alma-Ata, 274 p). (in Rus).

Bekmakhanova 1980 - Bekmakhanova, NE, Formirovanie mnogonatsional'nogo naseleniia Kazakhstana i Severnoi Kirgizii. Posledniaia chetvert' XVIII - 60-e gg. XIX vv., M., 280 p. (Bekmakhanova, NE 1980,Formation of the multinational population of Kazakhstan and Northern Kyrgyzstan. The last quarter of the XVIII - 60-ies. XIX centuries, M., 280 p.). (in Rus).

Dameshek 1986 - Dameshek, LM, Vnutrenniaia politika tsarizma i narody Sibiri (XIX - nachalo XX veka), Irkutsk, 165 p. (Dameshek, LM 1986, The internal policy of tsarism and the peoples of Siberia (XIX - the beginning of the XX century)), Irkutsk, $165 \mathrm{p})$. (in Rus).

Dameshek 2018 - Dameshek, LM, Sibirskie "inorodtsy' v imperskoi strategii vlasti (XVIII - nachalo XX v.), Irkutsk, 456 p. (Dameshek, LM 2018, Siberian "aliens" in the imperial strategy of power (XVIII early $X X$ century), Irkutsk, 456 p. (in Rus).

Ermekbaev 1999 - Ermekbaev, ZhA, Rossiiskie kazakhi v sostave RSFSR i SSSR v 1917-1991 gg, Omsk, 184 p. (Ermekbaev, ZhA1999, Russian Kazakhs in the RSFSR and the USSR in 19171991, Omsk, 184 p.). (in Rus).

Karikh 2004 - Karikh, EV, Mezhetnicheskie otnosheniia $v$ Zapadnoi Sibiri $v$ protsesse ee khoziaistvennogo osvoeniia. XIX - nachalo XX v, Tomsk, 232 p. (Karikh, EV 2004, Interethnic relations in Western Siberia in the process of its economic development. XIX - early XX century, Tomsk, 232 p). (in Rus).

Kraft 1898 - Kraft, II, Sbornik uzakonenii o kirgizakh stepnykh oblastei, Orenburg, 884 p. (Kraft, II 1898, Collection of legalizations about the Kirghiz of the steppe regions, Orenburg, 884 p). (in Rus).

Kuznetsov 1983 - Kuznetsov, VS, Tsinskaia imperiia na rubezhakh Tsentral'noi Azii (vtoraia polovina XVIII - pervaia polovina XIX v.), Novosibirsk, 124 p. (Kuznetsov, VS 1983, The Qing Empire on the borders of Central Asia (the second half of the XVIII - the first half of the XIX century), Novosibirsk, 124 p). (in Rus).

Kukharenko 2012 - Kukharenko, $A E$, Dorevoliutsionnaia i sovetskaia istoriografiia zemel'no-arendnoi politiki Kabineta v Altaiskom (gornom) okruge, Izvestiia Altaiskogo gosudarstvennogo universiteta, N4-2, P.146-150. (Kukharenko, AE 2012, Pre-Revolutionary and Soviet Historiography about Cabinet's Land-Rent Policy in the Altai (Mountain) District, Izvestiia Altaiskogo gosudarstvennogo universiteta, N4-2, P.146-150). (in Rus).

Lysenko, Anisimova 2013 - Lysenko, IUA, Anisimova, IV, Mezhetnicheskie protsessy na Altae v XVIII nachale XX veka (na primere russkogo i kazakhskogo etnosov), Barnaul, 176 p. (Lysenko, luA, Anisimova, IV 2013, Interethnic processes in the Altai in the XVIII - early XX century. (on the example of Russian and Kazakh ethnoses), Barnaul, 176 p). (in Rus).

Mendikulova 2002 - Mendikulova, GM, Aktual'nye problemy diasporologii v Kazakhstane,Otan tarikhi, №. 3-4, P.37-42. (Mendikulova, GM 2002, Actual problems of diasporology in Kazakhstan, Otan tarikhi, №. 3-4, P.37-42). (in Rus).

Naumova 2000 - Naumova, OB, Kazakhskaia diaspora v Rossii: etnicheskoe samosoznanie i migratsionnoe povedenie, Etnograficheskoe obozrenie, №3, P.60-73. (Naumova, OB 2000, 
Kazakh Diaspora in Russia: Ethnic Identity and Migration Behavior, Etnograficheskoe obozrenie, №3, P.60-73). (in Rus).

Oktiabr'skaia 1997 - Oktiabr'skaia, IV, Kazakhi Altaia. Istoriia i sovremennost', Etnograficheskoe obozrenie, № 6, P.92-102. (Oktiabr'skaia, IV 1997, Kazakhs of Altai. History and Modernity, Etnograficheskoe obozrenie, № 6, P.92-102). (in Rus).

Oktiabr'skaia et al. 2001 - Oktiabr'skaia, IV, Osipova LP, Nechiporenko OV, Turatinskie kazakhi. Sud'by natsional'nykh men'shinstv v Rossii, Etnografiia Altaia i sopredel'nykh territorii. Vyp. 4, Barnaul, P.29-34. (Oktiabr'skaia, IV, Osipova LP, Nechiporenko OV 2001, Turatin Kazakhs. Fate of national minorities in Russia, Etnografiia Altaia i sopredel'nykh territorii. Vyp. 4, Barnaul, P.2934). (in Rus).

Sherstova 2000 - Sherstova, LI, Vliianie gosudarstvennoi politiki na etnicheskie protsessy v luzhnoi Sibiri v pervoi polovine XIX v., Etnograficheskoe obozrenie, №4,P.102-108. (Sherstova, LI 2000, The influence of state policy on ethnic processes in South Siberia in the first half of the 19th century, Etnograficheskoe obozrenie, №4, P.102-108). (in Rus).

Sherstova 2003 - Sherstova, LI, Etnokul'turnye kontakty russkikh i narodov Sibiri v XVII-XIX vv.: evraziiskii aspect, Stepnoi krai Evrazii: istoriko-kul'turnye vzaimodeistviia i sovremennost'. Tezisy dokladov i soobshchenii III nauchnoi konferentsii, Astana - Omsk - Tomsk, P.75-77. (Sherstova, LI 2003, Etnokul'turnye kontakty russkikh i narodov Sibiri v XVII-XIX vv.: evraziiskii aspect, Ethnocultural contacts of Russians and peoples of Siberia in the XVII-XIX centuries: the Eurasian aspect, Astana - Omsk - Tomsk, P.75-77). (in Rus).

Shmurlo 1995 - Shmurlo, E, Russkie i kirgizy v doline verkhnei Bukhtarmy, Tsarskaia kolonizatsiia $v$ Kazakhstane. (Po materialam russkoi periodicheskoi pechati XIX veka), Almaty, P.21-79. (Shmurlo, E 1995, Russian and Kyrgyz in the valley of the upper Bukhtarma,Tsarskaia kolonizatsiia $v$ Kazakhstane. (Po materialam russkoi periodicheskoi pechati XIX veka), Almaty, P.21-79). (in Rus).

Trubetskoi 2002 - Trubetskoi, N, Vzgliad na russkuiu Istoriiu ne s Zapada, a s Vostoka,Osnovy Evraziistva, Moscow, P. 208-265. (Trubetskoi, N 2002, A glance at Russian History not from the West, but from the East, Osnovy Evraziistva, Moscow, P.208-265). (in Rus).

Umanskii 1980 - Umanskii, AP, Teleuty i russkie v XVII-XVIII vekakh, Novosibirsk, 296 p. (Umanskii, AP 1980, Teleuts and Russians in the XVII-XVIII centuries, Novosibirsk, 296 p). (in Rus).

Valikhanov 2001 - Valikhanov, EZh, Voprosy kazakhskoi gosudarstvennosti v XIX v, Otan tarikhy, № 3, P.53-56. (Valikhanov, EZh 2001, Questions of the Kazakh statehood in the XIX century, Otan tarikhy, № 3, P.53-56). (in Rus). 